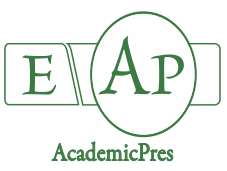

Notulae Botanicae Horti Agrobotanici Cluj-Napoca 48(4):2292-2305
DOI:10.15835/48412076

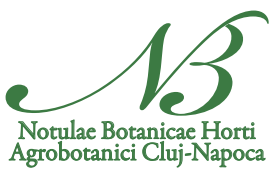

\title{
Effect of modified atmosphere packaging on nutraceutical quality and overall appearance of figs stored at $1{ }^{\circ} \mathrm{C}$
}

\author{
María T. MARTÍNEZ-DAMIÁN ${ }^{1}$, Omegar CRUZ-ARVIZU ${ }^{1}$, \\ Oscar CRUZ-ALVAREZ ${ }^{2 *}$
${ }^{1}$ Universidad Autónoma Chapingo, Department of Plant Sciences, Mexico-Texcoco Highway, 38.5, 56230, State of Mexico, Mexico; teremd13@gmail.com;omegar_cruz0302@hotmail.com
${ }^{2}$ Universidad Autónoma de Chihuahua, Faculty of Agrotechnological Sciences, Pascual Orozco Avenue, Campus 1, 31350,
Chihuahua, Mexico; ocruz@uach.mx ("corresponding author)

\begin{abstract}
Ficus carica L. has fruits with an exquisite flavour, colour and aroma. However, due to its morphological characteristics, it has a limited shelf life. The objective of this research was to evaluate the effect of modified atmosphere packaging on nutraceutical quality and the overall appearance of figs stored at $1{ }^{\circ} \mathrm{C}$. The experimental design used was completely randomized with four replications. The combined use of packaging and cold allowed to observe fruits with less weight loss and firmness, maintaining the values of citric acid and VC without significant changes. With the exception of the last evaluation period, no statistical variation was found in the content of TAn, TP and AC. On the other hand, it was also possible to observe a significant impact on the reduction of respiration and ethylene production, which could be corroborated with the conservation of sensory aspects of the fruit (texture, colour, appearance, marketing level, aroma and flavour) from very good to good. The generation of passive atmospheres (packaging) and the use of cold $\left(1{ }^{\circ} \mathrm{C}\right)$ are useful tools in maintaining the nutraceutical quality and appearance of fig fruits, aspects highly appreciated by consumers and marketers of this fruit.

Keywords: 'Black Mission'; ethylene production; Ficus carica L.; postharvest handling; respiration rate; sensory test

Abbreviations: ABTS: determination of free radical-scavenging ability by the use of a stable 2,2'-azinobis 3-ethylbenzothiazoline-6-sulfonic acid radical cation; AC: antioxidant capacity; EPTP: expanded polystyrene tray covered with pliofilm; EP: ethylene production; MA: modified atmosphere; TA: titratable acidity; TAn: total anthocyanins; TP: total phenols; TSS: total soluble solids; VC: Vitamin C; WL: weight loss.
\end{abstract}

\section{Introduction}

The Moraceae family consists of a wide variety of trees and shrubs, distributed in temperate and subtropical regions of Asia, America and Africa (Barolo et al., 2014). Among those of greatest economic importance (food and ornamental) stands out Ficus carica L. (common fig tree) (Kamiloglu and Capanoglu, 
2013), which has been cultivated and consumed since ancient times, due to its exquisite flavour, colour and aroma of its fruits (Villalobos et al., 2015b; Ersoy et al., 2017). Worldwide there is a planted area of 311,080 ha, located mainly in Morocco (60,533 ha), Iran (54,200 ha), Turkey (50,330 ha) and Algeria (40,932 ha), whose yields fluctuate between 1.57 and $5.96 \mathrm{t} \mathrm{ha}^{-1}$ (FAOSTAT, 2018).

Fig cultivation in Mexico dates back to the 1980s and is distributed in Veracruz, Michoacán, Baja California Sur, Puebla and Morelos with 79\% (1,838.60 ha) of the total planted area, where Baja California Sur it is the main producer with 602 ha (SIAP, 2019). The prevailing production system is the open field, characterized by the high incidence of pests and diseases, fruit rot during the rainy season, poor management of plantations and damage caused by frost (Mendoza-Castillo et al., 2017), which is manifested in obtaining crops with highly variable yields and low fruit quality (García-Ruiz et al., 2013), in addition to limiting the growth of the planted area. The implementation of modern irrigation systems, application of nutrients, conduction systems and complemented with the use of greenhouses, has allowed increasing the potential yield of the crop and quality of the harvested fruit (Mendoza-Castillo et al., 2017; Mendoza-Castillo et al., 2019), becoming a good economic alternative for various rural areas.

Among the reasons that could explain the growing demand for fig fruit is its excellent nutritional composition, characterized by its high content of fibre, amino acids (aspartic and glutamine), vitamins (thiamine and riboflavin), carotenoids (lutein, cryptoxanthin, lycopene and $\beta$-carotene), minerals (iron, calcium and potassium), polyphenolic compounds, sugars (fructose and glucose), organic acids (Wojdyło et al., 2016) and considerable concentrations of ascorbic acid (Allegra and Colelli, 2017). These compounds are characterized by their high antioxidant activity and their intake constitutes an important alternative for health care (Çalişkan and Aytekin, 2011; Barolo et al., 2014; Frías-Moreno et al., 2019), in particular of some types of cancer, diabetes, cardiovascular and neurodegenerative diseases (Slatner et al., 2011; Ersoy et al., 2017; Okatan et al., 2020).

Fig fruit is harvested at a point close to consumption maturity, and among the factors considered is its moderate respiration and ethylene production (Sozzi et al., 2005; Karabulut et al., 2009; Wojdyło et al., 2016), because it allows reaching the highest quality as a product for fresh consumption. In many production areas, the harvest indices used are not based on colour, turgor and solute concentration, which favours an increase in the respiration process, loss of turgor and susceptibility to attack by fungi and bacteria (Crisosto et al., 2010), with the subsequent development of unpleasant aromas (Çalişkan and Aytekin, 2011). It is for these reasons that the individual or combined implementation of refrigeration (Villalobos et al., 2015a), packaging (Villalobos et al., 2015b), biocidal substances (Cantín et al., 2011), ethylene inhibitors (1-methylcycloprene) as well as modified atmospheres (MA) and controlled (Irfan et al., 2013; Bahar and Lichter, 2018; Villalobos et al., 2018a), are tools that contribute to the preservation and maintenance of the quality characteristics of the fruit.

The use of cold is one of the most widely used conservation methods for the preservation of the organoleptic quality characteristics of fruit and vegetable products (Allegra and Colelli, 2017), because it favours a decrease in respiration rates, loss of water and ethylene production (Villalobos et al., 2015b). The addition of MA, through packaging permeable to $\mathrm{CO}_{2}$ and $\mathrm{O}_{2}$, can be an alternative that allows increasing the storage period of the fruit, given the sensitivity of the epidermis of fig fruit to water loss (Bouzo et al., 2012), with the relative advantage of being of lower cost, with respect to what would represent the use of controlled atmospheres (Villalobos et al., 2017; Villalobos et al., 2018b). That is why the objective of this study was to evaluate the effect of packaging in a modified atmosphere on the nutraceutical quality and the overall appearance of fig fruits stored at $1^{\circ} \mathrm{C}$. 


\section{Materials and Methods}

\section{Experiment location and plant material}

The experiment was carried out during the spring-summer cycle of 2018, in the fruit physiology laboratory of the Department of Plant Sciences belonging to the Universidad Autónoma Chapingo, State of Mexico, Mexico. The plant material consisted of 'Black Mission' fig fruits (late variety with dark epidermis and pale pink pulp), which were harvested from a commercial orchard with 3-year-old trees and managed under greenhouse conditions, located in the municipality of Axochiapan, Morelos, Mexico (18 28' 49.61" N; $9845^{\prime}$ $59.55^{\prime \prime} \mathrm{W}$ ) with an altitude of $1,017 \mathrm{~m}$ and average annual temperature of $23^{\circ} \mathrm{C}$. Among the crop management characteristics that can be mentioned, there is a planting density of 1 plant per $\mathrm{m}^{2}$ and 7 stems per plant with a "V" conduction system, the supply of nutrients was carried out through a nutrient solution modified for lettuce production described by Moreno-Pérez et al. (2015) and Steiner's universal solution (1984), for this a pressurized drip irrigation system was used, the micronutrients used $\left(\mathrm{mg} \mathrm{L}^{-1}\right)$ are: $\mathrm{Fe}(3), \mathrm{Mn}(0.5), \mathrm{Cu}(0.1)$ and $\mathrm{B}(0.6)$, where the major elements are shown in table 1 . Constant monitoring of $\mathrm{pH}(5.4 \pm 0.1)$ and electrical conductivity of $2.5 \mathrm{dS} \mathrm{m} \mathrm{m}^{-1}$ was maintained.

Table 1. Nutrient concentration of the nutrient solution used in the production of 'Black Mission' figs under greenhouse conditions (adapted from Steiner (1984) and Moreno-Pérez et al. (2015))

\begin{tabular}{|c|c|c|c|c|c|c|c|c|}
\hline \multirow{2}{*}{ Fertilizer source } & \multicolumn{5}{|c|}{ Cations (meq L-1) } & \multicolumn{3}{|c|}{ Anions (meq L $\left.{ }^{-1}\right)$} \\
\hline & $\mathrm{K}^{+}$ & $\mathrm{Ca}^{2+}$ & $\mathrm{Mg}^{2+}$ & $\mathrm{NH}_{4}^{+}$ & $\mathrm{H}^{+}$ & NO3- & $\mathrm{H}_{2} \mathrm{PO}_{4}$ & $\mathrm{SO}_{4}$ \\
\hline $\mathrm{Ca}(\mathrm{NO} 3)_{2} \cdot 4 \mathrm{H}_{2} \mathrm{O}$ & & 7 & & & & 7 & & \\
\hline $\mathrm{NH}_{4} \mathrm{H}_{2} \mathrm{PO}_{4}$ & & & & 1 & & & 1 & \\
\hline $\mathrm{KNO}_{3}$ & 5 & & & & & 5 & & 2 \\
\hline $\mathrm{K}_{2} \mathrm{SO}_{4}$ & 2 & & & & & & & 4 \\
\hline $\mathrm{MgSO}_{4} 7 \mathrm{H}_{2} \mathrm{O}$ & & & 4 & & & & & \\
\hline $\mathrm{H}_{3} \mathrm{PO}_{4}$ & & & & & 0.5 & & 0.5 & \\
\hline $\mathrm{H}_{2} \mathrm{SO}_{4}$ & & & & & 1 & & & \\
\hline Subtotal & 7 & 7 & 4 & 1 & 1.5 & 12 & 1.5 & 7 \\
\hline Cations - Anions & 20.5 & & & & & 20.5 & & \\
\hline
\end{tabular}

Note: $\mathrm{meq}=$ miliequivalents

\section{Experimental design}

The experiment was carried out under a completely random design with four replications. Two types of packaging were used (Clamshell and expanded polystyrene tray covered with pliofilm (EPTP)) stored at $1{ }^{\circ} \mathrm{C}$. The control treatments were those carried out at room temperature. The treatments consisted: 1$)=$ Clamshell $\left.+1{ }^{\circ} \mathrm{C} ; 2\right)=$ Clamshell $\left.+25 \pm 1{ }^{\circ} \mathrm{C} ; 3\right)$ EPTP $+1{ }^{\circ} \mathrm{C}$ and 4) EPTP $+25 \pm 1{ }^{\circ} \mathrm{C}$. Weight loss (WL), firmness, titratable acidity (TA), total soluble solids (TSS), vitamin C (VC), total anthocyanins (TAn), total phenols (TP) and antioxidant capacity (AC) were evaluated, as well as the colour, respiration and ethylene production (EP). In addition, some organoleptic characteristics associated with the quality of the fruit were evaluated through a sensory test. The determination of all the evaluated parameters was carried out every two days. The selected fruits were harvested at consumption maturity and those with deformities, incorrect ripening, damaged by pests and strange colours were eliminated.

\section{Evaluated parameters}

WL was determined as a percentage of initial weight. The firmness of the fruit (resistance to penetration and compression) was evaluated with a PTR-200N digital penetrometer mounted on an LTS-20 test machine (PCE Instruments, Spain) equipped with a $6 \mathrm{~mm}$ strut and the reading was recorded in Newtons. (N). $25 \mathrm{~g}$ of fruit were homogenized and juice was obtained in which the TA was evaluated according to the methodology proposed by the AOAC (AOAC, 1990) and the TSS concentration was quantified with a PAL-1 portable 
digital refractometer (Atago, Washington, USA). The VC content was estimated according to the method proposed by Jagota and Dani (1982) with slight modifications. $4 \mathrm{~g}$ of fruit were homogenized in $5 \mathrm{~mL}$ of $20 \%$ trichloroacetic acid (v:v), the mixture was left to rest for $5 \mathrm{~min}$ in cold (ice) and centrifuged for $20 \mathrm{~min}$ at 15,000 $\mathrm{rpm}$ at $4{ }^{\circ} \mathrm{C}$. Subsequently, a $0.2 \mathrm{~mL}$ aliquot of the supernatant of each sample was taken, to which $1.8 \mathrm{~mL}$ of distilled water and $0.2 \mathrm{~mL}$ of the $10 \%$ Folin-Ciocalteu reagent were added. The mixture was vigorously shaken and allowed to stand for $10 \mathrm{~min}$ to subsequently perform the absorbance reading at $760 \mathrm{~nm}$ using the Genesys ${ }^{\mathrm{wx}}$ $10 S$ UV-Vis spectrophotometer (Thermo Fisher Scientific, Florida, USA). The concentration was expressed in $\mathrm{mg} 100 \mathrm{~g}^{-1}$ of fresh weight through a standard curve of ascorbic acid. The content of TAn was determined according to the method proposed by Craker (1971), which consisted of taking $0.5 \mathrm{~g}$ of tissue and grinding it in a mortar with $1 \%$ methanol-HCl to later filter on Whatman paper with GF6 grade and record absorbance reading at $525 \mathrm{~nm}$ with the Genesys ${ }^{\text {nx }} 10 S$ UV-Vis Refractometer (Thermo Fisher Scientific, Florida, USA).

The results were calculated with the expression:

TAn (mg cyanidin-3-glucoside $100 \mathrm{~g}^{-1}$ of fresh weight $)=\left(\frac{\mathrm{A}^{*} \mathrm{MW} \mathrm{WF}^{*} \mathrm{DF}^{*} 1000}{\mathcal{E}^{*} \mathrm{~L}}\right) * 21$

where A is the absorbance at $525 \mathrm{~nm}, \mathrm{MW}$ corresponds to the molecular weight of cyanidin-3-glucoside (449.2), DF is the dilution factor, $\mathcal{E}$ is the molar absorptivity for cyanidin-3 -glucoside (26900) and $\mathrm{L}$, is the optical path of the cuvette $(10 \mathrm{~mm})$. The TP content was quantified with the method proposed by Waterman \& Mole (1994) with the following modifications: $2 \mathrm{~g}$ of tissue were taken to which $10 \mathrm{~mL}$ of extractor solution composed of $70 \%$ absolute ethyl alcohol were added (v:v) and homogenized, whose extract was stored at $4{ }^{\circ} \mathrm{C}$ for $12 \mathrm{~h} .150 \mu \mathrm{L}$ were taken and placed in flat-bottom tubes and the volume was added to $8 \mathrm{~mL}$ with distilled water, to later add $500 \mu \mathrm{L}$ of the Folin-Ciocalteu reagent $(2 \mathrm{~N})$, the mixture was stirred for $10 \mathrm{~s}$ and $1.5 \mathrm{~mL}$ of solution of $20 \%$ sodium carbonate, then it was left to rest for $2 \mathrm{~h}$ in conditions of total darkness and the absorbance reading was taken at $760 \mathrm{~nm}$ using the Genesys ${ }^{\mathrm{TM}} 10 \mathrm{~S}$ UV-Vis spectrophotometer (Thermo Fisher

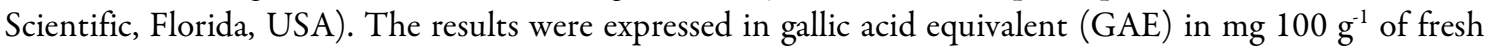
weight, taking as reference a standard curve of gallic acid. The AC was determined according to the ABTS method (2,2'azinobis (3-ethylbenzothiazolin-6-sulfonic acid)) described by Ozgen et al. (2006) with slight modifications; for this, the ABTS ${ }^{\bullet+}$ radical was formed After the reaction of ABTS $(7 \mathrm{mM})$ with potassium persulfate $(2.45 \mathrm{mM}$, final concentration) incubated at room temperature and in the dark for $16 \mathrm{~h}$ Once the $\mathrm{ABTS}^{\bullet+}$ radical had formed, it was diluted with PBS (phosphate buffer solution) ( $\mathrm{pH}$ 7.4) until obtaining an absorbance value of $0.7 \pm 0.1$ at $734 \mathrm{~nm}$ (maximum absorption length). On the other hand, $1 \mathrm{~g}$ of fruit tissue was taken to which $10 \mathrm{~mL}$ of ethyl alcohol at $70 \%$ absolute (v:v) was added, it was homogenized and left to rest for 24 hours. For the test, $200 \mu \mathrm{l}$ of the sample extract and $7.8 \mathrm{~mL}$ of the $\mathrm{ABTS}^{++}$solution was mixed, leaving it to rest for $2 \mathrm{~h}$ under conditions of total darkness, the absorbance reading was performed at $734 \mathrm{~nm}$ using the Genesys $^{\mathrm{TM}} 10 \mathrm{~S}$ UV-Vis spectrophotometer (Thermo Fisher scientific, USA). The results are expressed as $\mathrm{mMol}$ TE $100 \mathrm{~g}^{-1}$.

On the other hand, the determination of the respiration and ethylene production of the fruits was carried out, using the head-space method. The fruits were placed for $1 \mathrm{~h}$ in hermetically sealed glass vessels with a lid fitted with a silicone rubber septum. After this period of time, $5 \mathrm{~mL}$ of air (sample) was extracted with a hypodermic syringe (Nipro Medical Corporation, USA), where said sample was transferred to glass vacutainer ${ }^{\mathrm{TM}}$ tubes (Becton, Dickinson and Company, USA) to be stored at $-20^{\circ} \mathrm{C}$ for later reading. The samples were injected into a $3400 \mathrm{CX}^{\circ}$ gas chromatograph (Varian, USA), which has a framed capillary column $27.5 \mathrm{~cm}$ long, $0.32 \mathrm{~mm}$ internal diameter and $0.45 \mathrm{~mm}$ external diameter and $10 \mathrm{~mm}$ thick film open type with a porous layer of fused silica with a stationary base of Porapak type $\mathrm{Q}$. The temperature of the column, detector and injector was 80,170 and $150{ }^{\circ} \mathrm{C}$, respectively. As standard, 103 and $399 \mathrm{mg} \mathrm{L}^{-1}$ of ethylene and $\mathrm{CO}_{2}$ (INFRA, Mexico) was used, where helium was the entrainment gas, with a flow of $32.4 \mathrm{~mL} \mathrm{~min}{ }^{-1}$ and the amount of sample injected was $1 \mathrm{~mL}$, which was taken with a hypodermic syringe with similar capacity. Respiration and ethylene production results are expressed in $\mathrm{mg} \mathrm{CO}_{2} \mathrm{~kg} \mathrm{~h}^{-1}$ and $\mu \mathrm{g} \mathrm{C} \mathrm{H}_{4} \mathrm{~kg} \mathrm{~h}^{-1}$, respectively. 
The colour of the fruits was determined at the beginning and the end of the study, on two contrasting positions of the epidermis (equatorial zone of the fruit), using a SP $62^{\circ}$ sphere colourimeter (X-Rite, Michigan, USA) to obtain the parameters of brightness $\left(\mathrm{L}^{*}\right)$, hue angle $\left(\mathrm{h}^{\circ}\right)$ and chromaticity $\left(\mathrm{C}^{*}\right)$.

The sensory test was carried out by constructing a hedonic scale with five points $(0=$ very bad; $1=$ bad; $2=$ regular; $3=$ good; $4=$ very good and $5=$ excellent) and with the help of 30 judges with at least 18 years of age, the texture, colour, appearance, marketing level, aroma and flavour of the fruits were evaluated. Very important post-harvest aspects and characteristics for fig consumers and marketers.

\section{Statistical analysis}

An analysis of variance (ANOVA) and multiple comparisons of means were performed using the Tukey's test $(\mathrm{p} \leq 0.05)$. For the data obtained using the hedonic scale, a non-parametric analysis was carried out using the Kruskal-Wallis's test. In both cases, the statistical analysis package SAS version 9.0 was used.

\section{Results and Discussions}

The temperature and relative humidity surrounding the harvested product is one of the main factors to consider during postharvest handling, given its influence on respiration and transpiration processes (Allegra and Colelli, 2017). From the beginning of the experiment, the use of cold $\left(1{ }^{\circ} \mathrm{C}\right)$ statistically maintained the lowest WL (0.36-6.12\%) and the firmer fruits, where the EPTP was the best (Table 2). Behaviour associated with the increase in the concentration of $\mathrm{CO}_{2}$ in the atmosphere of the product that affects the conservation of the weight and firmness of the fruit (decrease in the rate of respiration and transpiration) (Bouzo et al., 2012; Núnéz-Castellano et al., 2012), and given that at a commercial level it is difficult to control the concentration of gases and relative humidity inside the package, supplementation with the use of cold improves its performance (Crisosto et al., 2010). In contrast, values between 1.89-5.51 N are reported by Irfan et al. (2013), in 'Poona' fig fruits stored at $1 \pm 0.5^{\circ} \mathrm{C}$ and $95-98 \%$ RH. Likewise, 'Roxo de Valinhos' fig fruits stored for eight days at $-0.5^{\circ} \mathrm{C}$ and $85-90 \% \mathrm{RH}$ with low-density polyethylene packaging and a thickness of $22 \mu \mathrm{M}$ showed the highest firmness (Neves et al., 2002), associated with lower permeability to $\mathrm{CO}_{2}$ and the preservation of the cell membrane (Villalobos et al., 2018). In a previous study carried out on the 'Black Mission' fig variety, Cantín et al. (2011) report that the breaking of the cold chain for at least 24 hours affects the loss of firmness, however, their data exceeded those observed in the fruits stored at Clamshell $+1{ }^{\circ} \mathrm{C}(8.29-6.82 \mathrm{~N})$, however, they were similar to those observed in the fruits stored with EPTP $(10.62-5.76 \mathrm{~N})$, which is associated with the low permeability of $\mathrm{CO}_{2}$ of the polystyrene and the excessive loss of water vapour.

The citric acid concentration did not show significant changes (Table 2). Results that are similar (0.15$0.20 \%$ ) with those observed by Baldoni et al. (2016), but lower than those indicated for this variety in commercial maturity (0.44\%) and consumption (0.38\%) (Crisosto et al., 2010).

In this study, from day 3 of storage, an accumulation of TSS was observed, especially in those fruits stored at room temperature $\left(25 \pm 1^{\circ} \mathrm{C}\right)$, where the clamshell showed less fluctuation and even on day 13 it was similar to the treatments at $1{ }^{\circ} \mathrm{C}$. In this regard, the effect of ambient temperature was apparent in the degradation of starch and subsequent generation reserve sweetness by accumulating simple sugars (fructose, glucose, among others) (Frías-Moreno et al., 2019), however, the degree of permeability to $\mathrm{CO}_{2}$ of the packaging materials also influenced (Villalobos et al., 2017), as indicated by Bouzo et al. (2012) when evaluating a polyethylene container (passive modified atmosphere) at 7, 14 and 21 days after harvest, found values of 8.9, 10.5 and $10.4^{\circ}$ Brix, respectively. 
Table 2. Weight loss, firmness, titratable acidity and total soluble solids in 'Black Mission' fig fruits with different packaging and stored at $1{ }^{\circ} \mathrm{C}$

\begin{tabular}{|c|c|c|c|c|c|c|c|c|}
\hline \multirow{3}{*}{ Treatments } & \multicolumn{8}{|c|}{ Days after storage } \\
\hline & 3 & 5 & 7 & 9 & 11 & 13 & 15 & 17 \\
\hline & \multicolumn{8}{|c|}{ Weight loss (\%) } \\
\hline Clamshell $+1{ }^{\circ} \mathrm{C}$ & $0.36 \mathrm{c}$ & $1.00 \mathrm{c}$ & $1.87 \mathrm{c}$ & $2.45 \mathrm{c}$ & $3.25 \mathrm{c}$ & $4.20 \mathrm{c}$ & $5.21 \mathrm{a}$ & $6.12 \mathrm{a}$ \\
\hline Clamshell $+25 \pm 1{ }^{\circ} \mathrm{C}$ & $1.14 \mathrm{~b}$ & $3.57 \mathrm{~b}$ & $6.08 \mathrm{~b}$ & $8.16 \mathrm{~b}$ & $10.64 \mathrm{~b}$ & $13.10 \mathrm{~b}$ & - & - \\
\hline $\mathrm{EPTP}+1{ }^{\circ} \mathrm{C}$ & $0.40 \mathrm{c}$ & $0.58 \mathrm{c}$ & $0.97 \mathrm{c}$ & $1.12 \mathrm{c}$ & $1.38 \mathrm{c}$ & $1.58 \mathrm{c}$ & $1.78 \mathrm{a}$ & $1.99 \mathrm{a}$ \\
\hline $\mathrm{EPTP}+25 \pm 1{ }^{\circ} \mathrm{C}$ & $2.42 \mathrm{a}$ & $7.60 \mathrm{a}$ & $12.96 \mathrm{a}$ & $17.11 \mathrm{a}$ & $22.10 \mathrm{a}$ & $27.31 \mathrm{a}$ & - & - \\
\hline \multirow[t]{2}{*}{$\mathrm{CV}(\%)$} & 77.19 & 87.62 & 86.56 & 87.35 & 87.11 & 87.05 & - & - \\
\hline & \multicolumn{8}{|c|}{ Firmness $(\mathrm{N})$} \\
\hline Clamshell $+1{ }^{\circ} \mathrm{C}$ & $8.28 \mathrm{a}$ & $8.29 \mathrm{a}$ & $7.19 \mathrm{ab}$ & $7.62 \mathrm{a}$ & $6.82 \mathrm{~b}$ & $7.54 \mathrm{a}$ & $8.47 \mathrm{a}$ & $7.83 \mathrm{a}$ \\
\hline Clamshell $+25 \pm 1^{\circ} \mathrm{C}$ & $5.01 \mathrm{~b}$ & $4.83 \mathrm{~b}$ & $4.54 \mathrm{~b}$ & $2.97 \mathrm{a}$ & $2.35 \mathrm{c}$ & $2.48 \mathrm{~b}$ & - & - \\
\hline $\mathrm{EPTP}+1{ }^{\circ} \mathrm{C}$ & $9.02 \mathrm{a}$ & $7.26 \mathrm{ab}$ & $9.68 \mathrm{a}$ & $7.60 \mathrm{a}$ & $10.62 \mathrm{a}$ & $8.13 \mathrm{a}$ & $7.46 \mathrm{a}$ & $5.76 \mathrm{a}$ \\
\hline $\mathrm{EPTP}+25 \pm 1{ }^{\circ} \mathrm{C}$ & $6.35 \mathrm{ab}$ & $6.66 \mathrm{ab}$ & $5.753 \mathrm{~b}$ & $3.351 \mathrm{a}$ & $3.37 \mathrm{bc}$ & $4.22 \mathrm{~b}$ & - & - \\
\hline \multirow[t]{2}{*}{$\mathrm{CV}(\%)$} & 22.05 & 18.60 & 28.18 & 41.39 & 56.01 & 41.75 & - & - \\
\hline & \multicolumn{8}{|c|}{ Titratable acidity (\% citric acid) } \\
\hline Clamshell $+1{ }^{\circ} \mathrm{C}$ & $0.22 \mathrm{a}$ & $0.19 \mathrm{a}$ & $0.17 \mathrm{a}$ & $0.15 \mathrm{a}$ & $0.13 \mathrm{a}$ & $0.12 \mathrm{a}$ & $0.13 \mathrm{a}$ & $0.15 \mathrm{a}$ \\
\hline Clamshell $+25 \pm 1^{\circ} \mathrm{C}$ & $0.17 \mathrm{a}$ & $0.16 \mathrm{a}$ & $0.11 \mathrm{a}$ & $0.14 \mathrm{a}$ & $0.12 \mathrm{a}$ & $0.17 \mathrm{a}$ & - & - \\
\hline $\mathrm{EPTP}+1{ }^{\circ} \mathrm{C}$ & $0.13 \mathrm{a}$ & $0.16 \mathrm{a}$ & $0.11 \mathrm{a}$ & $0.13 \mathrm{a}$ & $0.12 \mathrm{a}$ & $0.12 \mathrm{a}$ & $0.12 \mathrm{a}$ & $0.11 \mathrm{~b}$ \\
\hline $\mathrm{EPTP}+25 \pm 1{ }^{\circ} \mathrm{C}$ & $0.13 \mathrm{a}$ & $0.18 \mathrm{a}$ & $0.12 \mathrm{a}$ & $0.13 \mathrm{a}$ & $0.15 \mathrm{a}$ & $0.15 \mathrm{a}$ & - & - \\
\hline \multirow[t]{2}{*}{$\mathrm{CV}(\%)$} & 22.77 & 7.53 & 19.51 & 6.03 & 9.42 & 15.15 & - & - \\
\hline & \multicolumn{8}{|c|}{ Total soluble solids ( $\left.{ }^{\circ} \mathrm{Brix}\right)$} \\
\hline Clamshell $+1^{\circ} \mathrm{C}$ & $13.80 \mathrm{~b}$ & $15.00 \mathrm{~b}$ & $14.00 \mathrm{~b}$ & $16.67 \mathrm{a}$ & $12.67 \mathrm{a}$ & $12.33 \mathrm{~b}$ & $13.33 \mathrm{a}$ & $15.50 \mathrm{a}$ \\
\hline Clamshell $+25 \pm 1{ }^{\circ} \mathrm{C}$ & $18.17 \mathrm{a}$ & $15.17 \mathrm{~b}$ & $14.83 \mathrm{ab}$ & $16.00 \mathrm{a}$ & $14.83 a$ & $14.00 \mathrm{ab}$ & - & - \\
\hline $\mathrm{EPTP}+1{ }^{\circ} \mathrm{C}$ & $13.83 \mathrm{~b}$ & $13.67 \mathrm{~b}$ & $13.17 \mathrm{~b}$ & $16.50 \mathrm{a}$ & $12.83 \mathrm{a}$ & $12.83 \mathrm{~b}$ & $14.50 \mathrm{a}$ & $15.50 \mathrm{a}$ \\
\hline $\mathrm{EPTP}+25 \pm 1{ }^{\circ} \mathrm{C}$ & $14.50 \mathrm{ab}$ & $17.17 \mathrm{a}$ & $18.67 \mathrm{a}$ & $15.50 \mathrm{a}$ & $17.50 \mathrm{a}$ & $17.50 \mathrm{a}$ & - & - \\
\hline $\mathrm{CV}(\%)$ & 11.99 & 8.19 & 13.88 & 2.83 & 13.50 & 14.25 & - & - \\
\hline
\end{tabular}

Note:EPTP = expanded polystyrene tray covered with pliofilm; N: Newtons; CV: coefficient of variation. Values with the same letter within each column are not statistically different according to Tukey's test $(p \leq 0.05)$.

As can be seen in table 3, the fruits did not present significant differences $(\mathrm{p} \leq 0.05)$ related to VC content, with the exception of day 9 , where the treatment with clamshell $+25 \pm 1{ }^{\circ} \mathrm{C}$ showed the highest value

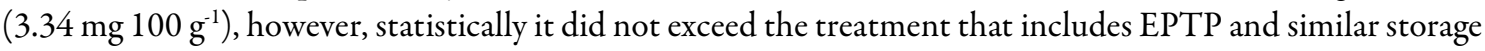
temperature $\left(3.17 \mathrm{mg} 100 \mathrm{~g}^{-1}\right)$. Similar results are reported in 'Poona' fig fruits stored at $1{ }^{\circ} \mathrm{C}$ by Irfan et al.

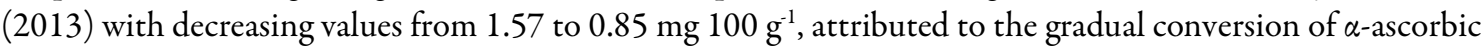
acid to dehydroascorbic acid, which modifies the active form of ascorbic acid and consequently its concentration in the fruit (Fadda et al., 2020). In other fruits such as strawberry (Fragaria $\times$ ananassa Duch.), a positive effect has been reported in the conservation of ascorbic acid during 10 days of storage, through the use of plastic covers (linear low-density polyethylene, recyclable, flexible, transparent, thermoplastic, semipermeable to gas exchange and water vapour) with respect to the control (without plastic cover) (NúnezCastellano et al., 2012). Regarding the behaviour of the results, it has been reported that processing and freezing favour the degradation of vitamin $\mathrm{C}$, due to its oxidation and the simultaneous use as an antioxidant agent during the stress generated by these practices (Quintero-Hilario et al., 2019; Estrada-Beltrán et al., 2020), however, the fig fruits remained intact, which leaves the possibility that it is related to the permeability of both $\mathrm{CO}_{2}$ and water vapour of the evaluated packages. 
Table 3. Content of bioactive compounds in 'Black Mission' fig fruits with different packaging and stored at $1{ }^{\circ} \mathrm{C}$

\begin{tabular}{|c|c|c|c|c|c|c|c|c|}
\hline \multirow{3}{*}{ Treatments } & \multicolumn{8}{|c|}{ Days after storage } \\
\hline & 3 & 5 & 7 & 9 & 11 & 13 & 15 & 17 \\
\hline & \multicolumn{8}{|c|}{ Vitamin C (mg $\left.100 \mathrm{~g}^{-1}\right)$} \\
\hline Clamshell $+1{ }^{\circ} \mathrm{C}$ & $3.03 \mathrm{a}$ & $3.25 \mathrm{a}$ & $2.99 \mathrm{a}$ & $2.94 \mathrm{~b}$ & $2.98 \mathrm{a}$ & $2.84 \mathrm{a}$ & $2.97 \mathrm{a}$ & $3.06 \mathrm{a}$ \\
\hline Clamshell $+25 \pm 1^{\circ} \mathrm{C}$ & $3.07 \mathrm{a}$ & $3.37 \mathrm{a}$ & $3.04 \mathrm{a}$ & $3.34 \mathrm{a}$ & $3.17 \mathrm{a}$ & $3.01 \mathrm{a}$ & - & - \\
\hline $\mathrm{EPTP}+1{ }^{\circ} \mathrm{C}$ & $3.04 \mathrm{a}$ & $3.06 \mathrm{a}$ & $3.09 \mathrm{a}$ & $2.89 \mathrm{~b}$ & $3.13 \mathrm{a}$ & $2.81 \mathrm{a}$ & $2.91 \mathrm{a}$ & $2.85 \mathrm{a}$ \\
\hline $\mathrm{EPTP}+25 \pm 1{ }^{\circ} \mathrm{C}$ & $3.10 \mathrm{a}$ & $2.98 \mathrm{a}$ & $3.10 \mathrm{a}$ & $3.17 \mathrm{ab}$ & $3.12 \mathrm{a}$ & $3.04 \mathrm{a}$ & - & - \\
\hline \multirow[t]{2}{*}{$\mathrm{CV}(\%)$} & 1.06 & 5.61 & 1.54 & 6.78 & 2.67 & 2.67 & - & - \\
\hline & \multicolumn{8}{|c|}{ Total anthocyanins (mg cyanidin-3-glucoside $100 \mathrm{~g}^{-1}$ ) } \\
\hline Clamshell $+1{ }^{\circ} \mathrm{C}$ & $43.18 \mathrm{a}$ & $39.55 \mathrm{a}$ & $41.43 \mathrm{a}$ & $44.29 \mathrm{a}$ & $66.89 \mathrm{a}$ & $39.50 \mathrm{ab}$ & $58.64 \mathrm{a}$ & $33.66 \mathrm{a}$ \\
\hline Clamshell $+25 \pm 1^{\circ} \mathrm{C}$ & $33.37 \mathrm{a}$ & $57.56 \mathrm{a}$ & $41.64 \mathrm{a}$ & $64.22 \mathrm{a}$ & $64.49 \mathrm{a}$ & $66.39 \mathrm{ab}$ & - & - \\
\hline $\mathrm{EPTP}+1^{\circ} \mathrm{C}$ & $31.73 \mathrm{a}$ & $43.60 \mathrm{a}$ & $63.77 \mathrm{a}$ & $41.62 \mathrm{a}$ & $42.94 \mathrm{a}$ & $35.43 \mathrm{~b}$ & $45.37 \mathrm{a}$ & $38.87 \mathrm{a}$ \\
\hline $\mathrm{EPTP}+25 \pm 1{ }^{\circ} \mathrm{C}$ & $41.33 \mathrm{a}$ & $59.68 \mathrm{a}$ & $44.60 \mathrm{a}$ & $52.30 \mathrm{a}$ & $32.65 \mathrm{a}$ & $73.19 \mathrm{a}$ & - & - \\
\hline \multirow[t]{2}{*}{$\mathrm{CV}(\%)$} & 13.18 & 17.31 & 19.37 & 17.36 & 27.90 & 30.59 & - & - \\
\hline & \multicolumn{8}{|c|}{ Total phenols (EAG mg $100 \mathrm{~g}^{-1}$ ) } \\
\hline Clamshell $+1{ }^{\circ} \mathrm{C}$ & $103.5 \mathrm{~b}$ & $98.6 \mathrm{a}$ & $95.0 \mathrm{a}$ & $103.0 \mathrm{a}$ & $93.5 \mathrm{a}$ & $68.8 \mathrm{~b}$ & $72.9 \mathrm{a}$ & $72.6 \mathrm{a}$ \\
\hline Clamshell $+25 \pm 1{ }^{\circ} \mathrm{C}$ & $162.7 \mathrm{a}$ & $122.2 \mathrm{a}$ & $93.6 \mathrm{a}$ & $104.5 \mathrm{a}$ & $97.1 \mathrm{a}$ & $77.7 \mathrm{~b}$ & - & - \\
\hline $\mathrm{EPTP}+1{ }^{\circ} \mathrm{C}$ & $97.5 \mathrm{~b}$ & $92.3 \mathrm{a}$ & $74.6 \mathrm{a}$ & $75.6 \mathrm{a}$ & $74.9 \mathrm{a}$ & $62.0 \mathrm{~b}$ & $99.6 \mathrm{a}$ & $82.5 \mathrm{a}$ \\
\hline $\mathrm{EPTP}+25 \pm 1{ }^{\circ} \mathrm{C}$ & $132.7 \mathrm{ab}$ & $97.7 \mathrm{a}$ & $90.8 \mathrm{a}$ & $90.0 \mathrm{a}$ & $124.1 \mathrm{a}$ & $149.2 \mathrm{a}$ & - & - \\
\hline \multirow[t]{2}{*}{$\mathrm{CV}(\%)$} & 20.92 & 11.21 & 9.22 & 12.50 & 18.04 & 39.09 & - & - \\
\hline & \multicolumn{8}{|c|}{ Antioxidant capacity $\left(\mathrm{mMol}\right.$ TE $\left.\left.100 \mathrm{~g}^{-1}\right)\right)$} \\
\hline Clamshell $+1^{\circ} \mathrm{C}$ & $0.33 \mathrm{a}$ & $0.38 \mathrm{a}$ & $0.52 \mathrm{~b}$ & $0.58 \mathrm{~b}$ & $0.63 \mathrm{~b}$ & $0.71 \mathrm{ab}$ & $0.83 \mathrm{a}$ & $0.82 \mathrm{a}$ \\
\hline Clamshell $+25 \pm 1^{\circ} \mathrm{C}$ & $0.41 \mathrm{a}$ & $0.42 \mathrm{a}$ & $0.65 \mathrm{a}$ & 0.72. a & $0.81 \mathrm{a}$ & $0.75 \mathrm{a}$ & - & - \\
\hline $\mathrm{EPTP}+1{ }^{\circ} \mathrm{C}$ & $0.32 \mathrm{a}$ & $0.41 \mathrm{a}$ & $0.50 \mathrm{~b}$ & $0.54 \mathrm{~b}$ & $0.62 \mathrm{~b}$ & $0.69 \mathrm{~b}$ & $0.86 \mathrm{a}$ & $0.83 \mathrm{a}$ \\
\hline $\mathrm{EPTP}+25 \pm 1^{\circ} \mathrm{C}$ & $0.39 \mathrm{a}$ & $0.40 \mathrm{a}$ & $0.66 \mathrm{a}$ & $0.73 \mathrm{a}$ & $0.82 \mathrm{a}$ & $0.76 \mathrm{a}$ & - & - \\
\hline $\mathrm{CV}(\%)$ & 10.57 & 3.67 & 12.52 & 13.26 & 13.21 & 3.93 & - & - \\
\hline
\end{tabular}

Note: EPTP = expanded polystyrene tray covered with pliofilm; CV: coefficient of variation. Values with the same letter within each column are not statistically different according to Tukey's test $(p \leq 0.05)$

The synthesis and accumulation of anthocyanins favour the presence of dark epidermis in fig fruit (Ersoy et al., 2017). The TAn content only showed a significant variation on day thirteen of storage, where the lowest value was observed in the fruits packed in EPTP and preserved at $1{ }^{\circ} \mathrm{C}$ (Table 3). In this regard, it has been reported that the high relative humidity inside the packages can help retain the initial concentration of pigments until the end of storage (Fadda et al., 2010). Likewise, these results can be attributed to the differences in gas permeability of the packaging used and to the ripening process of the fruits, that is, at the time that $\mathrm{CO}_{2}$ is fixed as $\mathrm{HCO}_{3}{ }^{-}$it modifies the $\mathrm{pH}$ of the tissue and increases the degradation of secondary colour pigments such as anthocyanins (Valle-Guadarrama et al., 2008). For their part, Slatnar et al. (2011) report that the anthocyanin concentration is severely affected by the loss of water and the progress in the ripening process, which could be indicated as one of the negative effects of ambient temperature on the appearance of the fruit.

Throughout the evaluation period, only at the beginning and on day thirteen, which corresponds to the last data collection for the fruits preserved at room temperature, significant values could be observed in the content of total phenols, where the treatment with EPTP $+25 \pm 1{ }^{\circ} \mathrm{C}$ was the most consistent. One of the attributes of phenols is their ability to act as active antioxidants, that is, to act as a defence method against the harmful activity of reactive oxygen species (Crisosto et al., 2010), a product of increased metabolism secondary induced by the fruit ripening process. Variation in environmental conditions during storage (storage temperature, light and oxygen availability) directly affect the structural stability of the phenolic compounds accumulated in the tissues (Okatan et al., 2020), although there is uneven behaviour in its concentration when the fruits are subjected to environmental temperature conditions (Villalobos et al., 2017). Zhang et al. (2008) 
when studying fruits in immature state, physiological maturity and consumption maturity of Chinese strawberry (Myrica rubra Sieb. and Zucc.) stored at $0 \pm 0.5^{\circ} \mathrm{C}$ and $20 \pm 0.5^{\circ} \mathrm{C}$, report a direct relationship between the time of storage and concentration of these compounds, where the maximum concentration was found at maturity of consumption. In this sense, the onset of cellular senescence of the fruit coincides with a slight substantial increase not only in phenols but also in anthocyanins and flavonoids, as part of the uncontrolled metabolism of senescent tissues. Regarding the last storage period, Villalobos et al. (2015b) point out that a higher moisture content during senescence may be a factor that can favour the oxidation of phenolic compounds, which suggests the search for a container permeable to gases and water in the form of vapour.

The fig fruit is an important source of fibre, vitamins, carotenoids, minerals, polyphenolic compounds, sugars and organic acids, all of them recognized for their nutritional importance and antioxidant activity (Wojdyło et al., 2016; Frías-Moreno et al., 2019). In this study it was observed that the treatments at room temperature showed the highest values of $\mathrm{AC}$, however, on day 13, the fruits packed with Clamshell and preserved at $1{ }^{\circ} \mathrm{C}$, showed similar behaviour (Table 3). Previous studies indicate that the fig fruit has phenolic compounds, such as hydroxycinnamic acid, flavones, flavonols and anthocyanins, but mainly epicatenin and luteolin-8-C-glucoside (Slatner et al., 2011), which are synthesized as part of the ripening process and colour changes (Villalobos et al., 2015a). Compounds that are relatively unstable in conditions of high temperature and light (Wojdyło et al., 2016; Okatan et al., 2020), which could explain the behaviour observed in the treatments with room temperature.

At the beginning of the evaluation period, the colour components did not show statistical variation between treatments. However, in the end, significant values were found for the hue angle $\left(h^{\circ}\right)(43.10$ and $56.08^{\circ}$ ), where the fruits preserved in cold were the highest, but it did not statistically exceed what was observed in the treatment with EPTP $+25 \pm 1{ }^{\circ} \mathrm{C}$ (Table 4). Results that do not exceed the $86.42 \pm 5.42^{\circ}$ reported by Sozzi et al. (2005) in 'Brown Turkey' fig fruits stored at $0{ }^{\circ} \mathrm{C}$ for fifteen days, however, these same authors report that this colour component showed a decreasing trend as the storage period progressed, that is, values of $94.33 \pm 5.4,91.00 \pm 4.58,89.25 \pm 5.74,88.54 \pm 5.40,88.03 \pm 6.70$ and $87.99 \pm 5.98^{\circ}$, at $1,3,5,8,10$ and 12 days of storage, respectively. Behaviour associated with the degradation of chlorophyll and carotenoids, and subsequent synthesis of anthocyanins, flavonoids and phenolic compounds (Harzallah et al., 2016), which implies a loss of the nutritional and functional value of the product.

Table 4. Colour components in 'Black Mission' fig fruits with different packaging and stored at $1{ }^{\circ} \mathrm{C}$

\begin{tabular}{|c|l|l|l|l|l|l|}
\hline \multirow{2}{*}{ Treatments } & \multicolumn{3}{|c|}{ Colour (0 days after storage) } & \multicolumn{2}{c|}{ Colour (15 days after storage) } \\
\cline { 2 - 6 } & \multicolumn{1}{|c|}{$\mathrm{L}^{*}$} & \multicolumn{1}{c|}{$\mathrm{C}^{*}$} & \multicolumn{1}{c|}{$\mathrm{h}^{\circ}$} & $\mathrm{C}^{*}$ & \multicolumn{1}{c|}{$\mathrm{h}^{\circ}$} \\
\hline Clamshell $+1{ }^{\circ} \mathrm{C}$ & $22.30 \mathrm{a}$ & $8.45 \mathrm{a}$ & $58.25 \mathrm{a}$ & $18.65 \mathrm{a}$ & $8.45 \mathrm{a}$ & $53.90 \mathrm{a}$ \\
\hline $\mathrm{Clamshell}+25 \pm 1{ }^{\circ} \mathrm{C}$ & $22.42 \mathrm{a}$ & $7.24 \mathrm{a}$ & $50.20 \mathrm{a}$ & $26.31 \mathrm{a}$ & $7.28 \mathrm{a}$ & $43.10 \mathrm{~b}$ \\
\hline $\mathrm{EPTP}+1{ }^{\circ} \mathrm{C}$ & $20.94 \mathrm{a}$ & $7.63 \mathrm{a}$ & $56.70 \mathrm{a}$ & $19.80 \mathrm{a}$ & $7.65 \mathrm{a}$ & $51.36 \mathrm{a}$ \\
\hline $\mathrm{EPTP}+25 \pm 1{ }^{\circ} \mathrm{C}$ & $21.66 \mathrm{a}$ & $7.30 \mathrm{a}$ & $68.20 \mathrm{a}$ & $22.58 \mathrm{a}$ & $7.53 \mathrm{a}$ & $56.08 \mathrm{a}$ \\
\hline $\mathrm{CV}(\%)$ & 2.70 & 6.30 & 11.04 & 13.52 & 5.67 & 9.62 \\
\hline
\end{tabular}

Note: EPTP = expanded polystyrene tray covered with pliofilm; CV: coefficient of variation. Values with the same letter within each column are not statistically different according to Tukey's test $(p \leq 0.05)$

Fig fruits are considered to have a climacteric pattern, that is, they continue with their maturation process after being harvested by moderately increasing their respiratory activity (Karabulut et al., 2009). In this work, the use of packaging and cold allowed a decrease in the respiratory rate of fig fruits with values that fluctuated between 14.35 and $36.41 \mathrm{mg} \mathrm{CO}_{2} \mathrm{kgh}^{-1}$, which were significantly lower than those observed in fruits packed and stored at room temperature (Table 5). Results that do not coincide with those indicated for 'Black Mission' fig fruits packed in pterephthalate polyethylene containers with a thickness of $330 \mu \mathrm{m}$ and stored at 5 ${ }^{\circ} \mathrm{C}$ for 16 days, which did not show variation with respect to the respiration values, whose range was 69.4- and 86.9- $\mathrm{mL} \mathrm{CO}_{2} \mathrm{~kg}^{-1} \mathrm{~h}^{-1}$ (Baldoni et al., 2016). Likewise, Crisosto et al. (2010) in the same variety indicate values between 47 and $67 \mathrm{~mL} \mathrm{CO}_{2} \mathrm{~kg}^{-1} \mathrm{~h}^{-1}$, which could suppose that the combined storage of packages and 
temperatures of $1{ }^{\circ} \mathrm{C}$, turns out to be beneficial for the conservation of the organoleptic quality of fig fruits, since our shelf life was similar to that reported by other authors (Neves et al., 2002; Villalobos et al., 2015b). On the other hand, Villalobos et al. (2015a) indicate that fig fruit is insensitive to cold damage and that it tolerates storage conditions between -1 and $0{ }^{\circ} \mathrm{C}$ with $90-95 \%$ relative humidity and its shelf life can be between 7 and 14 days. However, if packages are also selected with high permeability to $\mathrm{CO}_{2}$ and a slight reduction in the availability of $\mathrm{O}_{2}$, the respiration rate, ethylene production and the preservation of the firmness of the fruits may decrease (Crisosto et al., 2010; Bautista-Baños et al., 2017).

Table 5. Respiration rate and ethylene production in 'Black Mission' fig fruits with different packaging and stored at $1^{\circ} \mathrm{C}$

\begin{tabular}{|c|c|c|c|c|c|c|c|c|}
\hline \multirow{3}{*}{ Treatments } & \multicolumn{8}{|c|}{ Days after storage } \\
\hline & 3 & 5 & 7 & 9 & 11 & 13 & 15 & 17 \\
\hline & \multicolumn{8}{|c|}{ Respiration $\left(\mathrm{mg} \mathrm{CO}_{2} \mathrm{~kg} \mathrm{~h}^{-1}\right)$} \\
\hline Clamshell $+1{ }^{\circ} \mathrm{C}$ & $15.86 \mathrm{~b}$ & $17.01 \mathrm{~b}$ & $21.90 \mathrm{~b}$ & $25.30 \mathrm{~b}$ & $29.87 \mathrm{~b}$ & $31.35 \mathrm{~b}$ & $32.01 \mathrm{a}$ & $35.89 \mathrm{a}$ \\
\hline Clamshell $+25 \pm 1^{\circ} \mathrm{C}$ & $46.25 \mathrm{a}$ & $58.23 \mathrm{a}$ & $66.16 \mathrm{a}$ & $69.58 \mathrm{a}$ & $76.35 \mathrm{a}$ & $78.08 \mathrm{a}$ & - & - \\
\hline $\mathrm{EPTP}+1{ }^{\circ} \mathrm{C}$ & $14.35 \mathrm{~b}$ & $18.25 \mathrm{~b}$ & $23.67 \mathrm{~b}$ & $28.98 \mathrm{~b}$ & $35.21 \mathrm{~b}$ & $35.25 \mathrm{~b}$ & $35.98 \mathrm{a}$ & $36.41 \mathrm{a}$ \\
\hline $\mathrm{EPTP}+25 \pm 1^{\circ} \mathrm{C}$ & $47.18 \mathrm{a}$ & $56.06 \mathrm{a}$ & $69.25 \mathrm{a}$ & $71.35 \mathrm{a}$ & $75.56 \mathrm{a}$ & $76.25 \mathrm{a}$ & - & - \\
\hline \multirow[t]{2}{*}{$\mathrm{CV}(\%)$} & 51.17 & 52.90 & 49.71 & 44.49 & 40.17 & 39.80 & - & - \\
\hline & \multicolumn{8}{|c|}{ Ethylene production $\left(\mu \mathrm{L} \mathrm{C}_{2} \mathrm{H}_{4} \mathrm{~kg} \mathrm{~h}^{-1}\right)$} \\
\hline Clamshell $+1^{\circ} \mathrm{C}$ & $0.50 \mathrm{~b}$ & $0.55 \mathrm{~b}$ & $0.61 \mathrm{~b}$ & $0.78 \mathrm{~b}$ & $0.78 \mathrm{~b}$ & $0.90 \mathrm{~b}$ & $0.92 \mathrm{a}$ & $0.99 \mathrm{a}$ \\
\hline Clamshell $+25 \pm 1{ }^{\circ} \mathrm{C}$ & $3.50 \mathrm{a}$ & $3.90 \mathrm{a}$ & $4.90 \mathrm{a}$ & $5.20 \mathrm{a}$ & $5.80 \mathrm{a}$ & $5.70 \mathrm{a}$ & - & - \\
\hline $\mathrm{EPTP}+1{ }^{\circ} \mathrm{C}$ & $0.45 \mathrm{~b}$ & $0.48 \mathrm{~b}$ & $0.48 \mathrm{~b}$ & $0.50 \mathrm{~b}$ & $0.64 \mathrm{~b}$ & $0.68 \mathrm{~b}$ & $0.71 \mathrm{a}$ & $0.89 \mathrm{a}$ \\
\hline $\mathrm{EPTP}+25 \pm 1{ }^{\circ} \mathrm{C}$ & $4.01 \mathrm{a}$ & $4.30 \mathrm{a}$ & $4.70 \mathrm{a}$ & $5.10 \mathrm{a}$ & $5.40 \mathrm{a}$ & $5.50 \mathrm{~b}$ & - & - \\
\hline $\mathrm{CV}(\%)$ & 78.01 & 77.93 & 79.66 & 77.97 & 77.64 & 75.34 & - & - \\
\hline
\end{tabular}

Note: EPTP = expanded polystyrene tray covered with pliofilm; CV: coefficient of variation. Values with the same letter within each column are not statistically different according to Tukey's test $(\mathrm{p} \leq 0.05)$

The use of refrigeration favoured a significant reduction in $\mathrm{EP}\left(0.45-0.99 \mu \mathrm{L} \mathrm{C}_{2} \mathrm{H}_{4} \mathrm{~kg} \mathrm{~h}^{-1}\right)$, with respect to the values found in fruits stored with similar packages $\left(3.5-5.8 \mu \mathrm{L} \mathrm{C}_{2} \mathrm{H}_{4} \mathrm{~kg} \mathrm{~h}^{-1}\right)$ but at ambient temperature. Fig fruit is characterized by showing a moderate production of ethylene (Sozzi et al., 2005), however, adverse factors such as temperature and the advance in the ripening process, can favour autocatalysis and a higher concentration of this hormone (Bahar and Lichter, 2018). With this, changes in colour, concentration of sugars and loss of firmness (Villalobos et al., 2018b). In this sense, the reduction of these processes can be achieved with the application of rapid cooling and storage in MA (Harzallah et al., 2016).

The results of the sensory test are shown in Table 6. The texture of the fruits did not show significant changes the first seven days of evaluation, however, after nine days of storage, an important effect of packaging and cold is observed $\left(1{ }^{\circ} \mathrm{C}\right)$ by keeping the fruits in very good to good condition, which is significant as a preservation method. Furthermore, the colour of the fruits remained unchanged. In this regard, King et al. (2012) point out one of the most appreciated characteristics in figs is the colour of their epidermis, because both consumers and marketers establish a direct relationship of this characteristic with the quality of the fruit, that is, homogeneous tonality and fresh appearance (Kamiloglu and Capanoglu, 2013), conditions that can be achieved with the management of the appropriate temperature as in this study.

The general appearance of the fruit is decisive as a selection and purchase factor, so it is of great importance to maintain this characteristic for as long as possible. The fruits stored with refrigeration remained without significant changes (excellent appearance) until the eleven day of storage. However, for day fifteen and seventeen there were slight changes (very good appearance), in which the combined effect of storage temperature and packaging is visible. Thus, the fruits stored at room temperature showed a slight decrease in their appearance (very good appearance) (seven days after storage) behaviour that remained unchanged until day eleven day after storage, when the fruits showed visible symptoms of deterioration when manifesting an 
appearance regular. In this regard, one of the most common causes associated with the deterioration of fig fruit is found with the use of inappropriate storage temperatures (Irfan et al., 2013), due to its great susceptibility to water loss, browning, changes colour and texture, surface pitting and microbial deterioration, among others (Villanueva et al., 2018a).

Table 6. Kruskal-Wallis range means of aspects of sensory quality in 'Black Mission' fig fruits with different packaging and stored at $1{ }^{\circ} \mathrm{C}$

\begin{tabular}{|c|c|c|c|c|c|c|c|c|}
\hline \multirow{3}{*}{ Treatments } & \multicolumn{8}{|c|}{ Days after storage } \\
\hline & 3 & 5 & 7 & 9 & 11 & 13 & 15 & 17 \\
\hline & \multicolumn{8}{|c|}{ Texture } \\
\hline Clamshell $+1{ }^{\circ} \mathrm{C}$ & $5.0 \mathrm{a}$ & $5.0 \mathrm{a}$ & $4.7 \mathrm{a}$ & $4.7 \mathrm{a}$ & $4.1 \mathrm{a}$ & $3.0 \mathrm{a}$ & $4.0 \mathrm{a}$ & $3.0 \mathrm{a}$ \\
\hline Clamshell $+25 \pm 1^{\circ} \mathrm{C}$ & $5.0 \mathrm{a}$ & $4.5 \mathrm{a}$ & $4.3 \mathrm{a}$ & $3.3 \mathrm{~b}$ & $3.0 \mathrm{~b}$ & $1.7 \mathrm{~b}$ & - & - \\
\hline $\mathrm{EPTP}+1{ }^{\circ} \mathrm{C}$ & $5.0 \mathrm{a}$ & $4.7 \mathrm{a}$ & $5.0 \mathrm{a}$ & $4.3 \mathrm{a}$ & $4.0 \mathrm{a}$ & $3.7 \mathrm{a}$ & $4.0 \mathrm{a}$ & $3.7 \mathrm{a}$ \\
\hline \multirow[t]{2}{*}{$\mathrm{EPTP}+25 \pm 1^{\circ} \mathrm{C}$} & $5.0 \mathrm{a}$ & $5.0 \mathrm{a}$ & $4.3 \mathrm{a}$ & $3.7 \mathrm{~b}$ & $3.3 \mathrm{~b}$ & $2.2 \mathrm{~b}$ & - & - \\
\hline & \multicolumn{8}{|c|}{ Colour } \\
\hline Clamshell $+1{ }^{\circ} \mathrm{C}$ & $4.3 \mathrm{a}$ & $4.0 \mathrm{a}$ & $3.7 \mathrm{a}$ & $4.7 \mathrm{a}$ & $4.3 \mathrm{a}$ & $4.2 \mathrm{a}$ & $4.4 \mathrm{a}$ & $4.8 \mathrm{a}$ \\
\hline Clamshell $+25 \pm 1{ }^{\circ} \mathrm{C}$ & $4.3 \mathrm{a}$ & $4.3 \mathrm{a}$ & $4.0 \mathrm{a}$ & $4.0 \mathrm{a}$ & $4.8 \mathrm{a}$ & $5.0 \mathrm{a}$ & - & - \\
\hline $\mathrm{EPTP}+1{ }^{\circ} \mathrm{C}$ & $4.3 \mathrm{a}$ & $4.3 \mathrm{a}$ & $3.7 \mathrm{a}$ & $4.7 \mathrm{a}$ & $4.0 \mathrm{a}$ & $4.0 \mathrm{a}$ & $4.5 \mathrm{a}$ & $4.5 \mathrm{a}$ \\
\hline \multirow[t]{2}{*}{$\mathrm{EPTP}+25 \pm 1^{\circ} \mathrm{C}$} & $4.7 \mathrm{a}$ & $4.7 \mathrm{a}$ & $4.5 \mathrm{a}$ & $4.3 \mathrm{a}$ & $3.8 \mathrm{a}$ & $5.0 \mathrm{a}$ & - & - \\
\hline & \multicolumn{8}{|c|}{ Appearance } \\
\hline Clamshell $+1{ }^{\circ} \mathrm{C}$ & $5.0 \mathrm{a}$ & $5.0 \mathrm{a}$ & $5.0 \mathrm{a}$ & $5.0 \mathrm{a}$ & $5.0 \mathrm{a}$ & $5.0 \mathrm{a}$ & $4.0 \mathrm{a}$ & $4.0 \mathrm{a}$ \\
\hline Clamshell $+25 \pm 1{ }^{\circ} \mathrm{C}$ & $5.0 \mathrm{a}$ & $4.7 \mathrm{a}$ & $3.3 \mathrm{~b}$ & $3.7 \mathrm{~b}$ & $3.7 \mathrm{~b}$ & $2.0 \mathrm{~b}$ & - & - \\
\hline $\mathrm{EPTP}+1^{\circ} \mathrm{C}$ & $5.0 \mathrm{a}$ & $5.0 \mathrm{a}$ & $5.0 \mathrm{a}$ & $5.0 \mathrm{a}$ & $5.0 \mathrm{a}$ & $5.0 \mathrm{a}$ & $4.1 \mathrm{a}$ & $4.0 \mathrm{a}$ \\
\hline \multirow[t]{2}{*}{$\mathrm{EPTP}+25 \pm 1^{\circ} \mathrm{C}$} & $5.0 \mathrm{a}$ & $5.0 \mathrm{a}$ & $4.0 \mathrm{~b}$ & $4.0 \mathrm{~b}$ & $3.7 \mathrm{~b}$ & $2.0 \mathrm{~b}$ & - & - \\
\hline & \multicolumn{8}{|c|}{ Marketing level } \\
\hline Clamshell $+1^{\circ} \mathrm{C}$ & $5.0 \mathrm{a}$ & $5.0 \mathrm{a}$ & $5.0 \mathrm{a}$ & $5.0 \mathrm{a}$ & $4.7 \mathrm{a}$ & $4.5 \mathrm{a}$ & $4.0 \mathrm{a}$ & $3.6 \mathrm{a}$ \\
\hline Clamshell $+25 \pm 1^{\circ} \mathrm{C}$ & $5.0 \mathrm{a}$ & $4.7 \mathrm{a}$ & $3.7 \mathrm{~b}$ & $4.0 \mathrm{a}$ & $3.0 \mathrm{~b}$ & $1.3 \mathrm{c}$ & - & - \\
\hline $\mathrm{EPTP}+1{ }^{\circ} \mathrm{C}$ & $5.0 \mathrm{a}$ & $5.0 \mathrm{a}$ & $5.0 \mathrm{a}$ & $5.0 \mathrm{a}$ & $4.8 \mathrm{a}$ & $4.5 \mathrm{a}$ & $4.0 \mathrm{a}$ & $3.5 \mathrm{a}$ \\
\hline \multirow[t]{2}{*}{$\mathrm{EPTP}+25 \pm 1{ }^{\circ} \mathrm{C}$} & $5.0 \mathrm{a}$ & $5.0 \mathrm{a}$ & $4.7 \mathrm{a}$ & $4.0 \mathrm{a}$ & $3.3 \mathrm{ab}$ & $2.3 \mathrm{~b}$ & - & - \\
\hline & \multicolumn{8}{|c|}{ Aroma } \\
\hline Clamshell $+1{ }^{\circ} \mathrm{C}$ & $3.0 \mathrm{a}^{\mathrm{z}}$ & $3.3 \mathrm{a}$ & $3.0 \mathrm{a}$ & $4.0 \mathrm{a}$ & $4.0 \mathrm{a}$ & $4.5 \mathrm{a}$ & $4.2 \mathrm{a}$ & $3.3 \mathrm{~b}$ \\
\hline Clamshell $+25 \pm 1^{\circ} \mathrm{C}$ & $3.0 \mathrm{a}$ & $3.3 \mathrm{a}$ & $4.0 \mathrm{a}$ & $4.3 \mathrm{a}$ & $3.5 \mathrm{a}$ & $1.7 \mathrm{~b}$ & - & - \\
\hline $\mathrm{EPTP}+1{ }^{\circ} \mathrm{C}$ & $3.0 \mathrm{a}$ & $3.0 \mathrm{a}$ & $3.0 \mathrm{a}$ & $3.3 \mathrm{a}$ & $3.5 \mathrm{a}$ & $3.8 \mathrm{a}$ & $4.2 \mathrm{a}$ & $4.2 \mathrm{a}$ \\
\hline \multirow[t]{2}{*}{$\mathrm{EPTP}+25 \pm 1{ }^{\circ} \mathrm{C}$} & $3.0 \mathrm{a}$ & $3.3 \mathrm{a}$ & $3.7 \mathrm{a}$ & $4.7 \mathrm{a}$ & $3.2 \mathrm{a}$ & $2.5 \mathrm{~b}$ & - & - \\
\hline & \multicolumn{8}{|c|}{ Flavour } \\
\hline Clamshell $+1{ }^{\circ} \mathrm{C}$ & $3.0 \mathrm{a}$ & $4.3 \mathrm{a}$ & $4.7 \mathrm{a}$ & $4.7 \mathrm{a}$ & $4.0 \mathrm{a}$ & $4.7 \mathrm{a}$ & $4.5 \mathrm{a}$ & $4.5 \mathrm{a}$ \\
\hline Clamshell $+25 \pm 1^{\circ} \mathrm{C}$ & $3.7 \mathrm{a}$ & $4.3 \mathrm{a}$ & $4.7 \mathrm{a}$ & $4.7 \mathrm{a}$ & $4.7 \mathrm{a}$ & $0.9 \mathrm{~b}$ & - & - \\
\hline $\mathrm{EPTP}+1{ }^{\circ} \mathrm{C}$ & $3.3 \mathrm{a}$ & $4.3 \mathrm{a}$ & $4.3 \mathrm{a}$ & $4.7 \mathrm{a}$ & $3.3 \mathrm{a}$ & $4.3 \mathrm{a}$ & $4.7 \mathrm{a}$ & $4.8 \mathrm{a}$ \\
\hline $\mathrm{EPTP}+25 \pm 1{ }^{\circ} \mathrm{C}$ & $3.7 \mathrm{a}$ & $4.3 \mathrm{a}$ & $4.7 \mathrm{a}$ & $4.7 \mathrm{a}$ & $4.3 \mathrm{a}$ & $1.3 \mathrm{~b}$ & - & - \\
\hline
\end{tabular}

Note: EPTP = expanded polystyrene tray covered with pliofilm. Values correspond to comparisons of means of ranges by treatments for a completely randomized design (Conover, 1980)

As mentioned previously, the appearance and colour of the fruits are two important aspects of the acceptance of the product by both consumers and marketers. In this study, with one week of storage, the level of commercialization showed significant changes, where the treatments associated with refrigeration (Clamshell $+1{ }^{\circ} \mathrm{C}$ and EPTP $+1{ }^{\circ} \mathrm{C}+$ ) and the treatment with EPTP $+25 \pm 1{ }^{\circ} \mathrm{C}$ showed values on the scale of 5.0 and 4.7, which correspond to fruits with excellent and very good commercialization levels, respectively. Similar behaviour was observed for day 11, where the fruits stored with cold showed fruits with a very good level of commercialization, however, those fruits packed in EPTP and room temperature showed a similar quality (3.3). On day 13, a slight decrease in the level of commercialization was observed in the fruits stored in 
cold, and this was maintained until the end of the evaluation. In contrast, the fruits preserved at room temperature and packed with Clamshell and EPTP, presented values that correspond to bad and fair, which is manifested in the reduction of $60 \%$ of the price with respect to fruits of excellent quality (Wojdyło et al., 2016). In this sense, a greater influence of temperature was observed, however, among the packages used, the EPTP showed the best results, attributed to its better permeability, that is, an adequate balance between the concentration of $\mathrm{CO}_{2}$ and $\mathrm{O}_{2}$, in the that the firmness and external appearance (colour and brightness of the epidermis) are maintained (Villalobos et al., 2015b).

The gradual change in flavour and aroma of fruit and vegetable products is a consequence of the ripening process, that is, the use of reserve substrates (polysaccharides and organic acids) to obtain chemical energy and the simultaneous synthesis of volatile compounds (Salas et al., 2017; Frías-Moreno et al., 2019; Estrada-Beltrán et al., 2020), processes that make them attractive to be consumed. The use of packaging and refrigeration favoured for eleven days the perception of preservation of the flavour and aroma of the fruits, and even in the following evaluation there was an improvement of these attributes (from good to very good) and fall slowly, with respect to treatments in room temperature, where its fall was abrupt and with the appearance of unpleasant flavours and aromas. In this regard, the effect of temperature on increasing respiration is well known, which affects the solubilisation and use of reserve substances (polysaccharides and organic acids) (Bouzo et al., 2012; Bautista-Baños et al., 2017; Villalobos et al., 2018a). It is during the breathing process when the product loses many of its nutritional and functional properties, which are highly appreciated by consumers who are concerned about a diet that contributes to the care of their health (Harzallah et al., 2016; Ersoy et al., 2017; Bahar and Lichter, 2018).

\section{Conclusions}

The fig fruit responds satisfactorily to the use of packaging and cold $\left(1{ }^{\circ} \mathrm{C}\right)$. The use of expanded polystyrene trays covered with pliofilm was efficient in significantly reducing weight loss, maintaining firmness, total soluble solids, respiration, and ethylene production, although in the last two parameters its behaviour was similar to Clamshell. It does not cause changes in titratable acidity, vitamin $\mathrm{C}$ content and colour of the fruits. Compounds valued for their antioxidant activity, such as anthocyanins and total phenols, were maintained with the least degradation. On the other hand, the generation of passive atmospheres (packaging) and cold (1 ${ }^{\circ} \mathrm{C}$ ) significantly favoured the conservation (very good to good) of the sensory characteristics of the fig fruit (appearance, texture, colour, commercialization level, aroma and flavour).

\section{Authors' Contributions}

Conceptualization: MTMD; Data collection and analysis: MTMD and OCA; Review and structure of the article: OCA and MTMD. All authors read and approved the final manuscript.

\section{Acknowledgements}

The authors are grateful for the technical, financial and administrative support provided by the Universidad Autónoma Chapingo and the Universidad Autónoma de Chihuahua for the execution of this study. 


\section{Conflict of Interests}

The authors declare that there are no conflicts of interest related to this article.

\section{References}

Allegra A, Colelli G (2017). The effect of passive atmosphere on quality of 'Dottato' breba fig stored at low temperature. Acta Horticulturae 1173:315-318. https://doi.org/10.17660/ActaHortic.2017.1173.54

AOAC (1990). Association of Official Analytical Chemists. Official Methods and Analysis (14th ed). Arlington.

Bahar A, Lichter A (2018). Effect of controlled atmosphere on the storage potential of Ottomanit fig fruit. Scientia Horticulturae 227:196-201. https://doi.org/10.1016/jscienta.2017.09.036

Baldoni D, Ventura-Aguilar R., Hernández-López M, Corona M, Barrera-Necha L, Correa-Pacheco Z, Bautista-Baños S (2016). Calidad postcosecha de higos 'Black Mission' tratados con cubiertas naturales [Postharvest quality of ficus 'Black Mission' treated with natural coatings]. Revista Iberoamericana de Tecnología Postcosecha 17(2):267-275. https://www.redalyc.org/articulo.oa?id=81349041014

Barolo MI, Ruiz MN, López SN (2014). Ficus carica L. (Moraceae): An ancient source of food and health. Food Chemistry 164:119-27. https://doi.org/10.1016/j.foodchem.2014.04.112

Bautista-Baños S, Ventura-Aguilar RI, Correa-Pacheco Z, Corona-Rangel ML (2017). Chitosan: a versatile antimicrobial polysaccharide for fruit and vegetables in postharvest - a review. Revista Chapingo Serie Horticultura 23(2):103121. https://doi.org/10.5154/r.rchsh.2016.11.030

Bouzo CA, Travadelo M, Gariglio NF (2012). Effect of different packaging materials on postharvest quality of fresh fig fruit. International Journal of Agriculture \& Biology 14:821-825. https://www.fspublishers.org/Issue.php? $y=20128 V_{-}$no $=148$ categoryID $=99$

Çalişkan O, Aytekin PA (2011). Phytochemical and antioxidant properties of selected fig (Ficus carica L.) accessions from the eastern Mediterranean region of Turkey. Scientia Horticulturae 128(4):473-478. https://doi.org/10.1016/j.scienta.2011.02.023

Cantín M, Palou L, Bremer V, Michailides TJ, Crisosto CJ (2011). Evaluation of the use of sulfur dioxide to reduce postharvest losses on dark and green figs. Postharvest Biology and Technology 59(2):150-158. https://doi.org/10.1016/j.postharvbio.2010.09.016

Conover WJ (1980). Practical nonparametric Statistics. John Wiley \& Sons (2nd ed), New York.

Craker LE (1971). Postharvest color promotion in cranberry with ethylene. HortScience 6:137-139.

Crisosto CH, Bremer V, Ferguson L, Crisosto GM (2010). Evaluating quality attributes of four fresh fig (Ficus carica L.) cultivars harvested at two maturity stages. HortScience 45(4):707-710. https://doi.org/10.21273/HORTSCI.45.4.707

Ersoy N, Gozlekci S, Gok V, Yilmaz S (2017). Fig (Ficus carica L.) fruit: some physical and chemical properties. Acta Horticulturae 1173:329-334. https://doi.org/10.17660/ActaHortic.2017.1173.57

Estrada-Beltrán A, Salas-Salazar NA, Parra-Quezada RA, González-Franco AC, Soto-Caballero MC, Rodríguez-Roque MJ, ... Chávez-Martinez A (2020). Effect of conventional and organic fertilizers on volatile compounds of raspberry fruit. Notulae Botanicae Horti Agrobotanici Cluj-Napoca, 48(2): 862-870. https://doi.org/10.15835/nbha48211810

Fadda A, Amedeo P, Azara E, D'Aquino S (2020). Effect of modified atmosphere packaging on overall appearance and nutraceutical quality of pot marigold held at $5{ }^{\circ} \mathrm{C}$. Food Research International 134:109248. https://doi.org/10.1016/j.foodres.2020.109248

FAOSTAT (2018). Food and Agriculture Organization of the United Nations. Retrieved 2020 June 18 from http://www.fao.org/faostat/es/\#data/QC

Fogliano V, Verde V, Randazzo G, Ritieni A (1999). Method for measuring antioxidant activity and its application to monitoring the antioxidant capacity of wines. Journal of Agricultural and Food Chemistry 47:1035-1040. https://doi.org/10.1021/jf980496s

Frías-Moreno MN, Olivas-Orozco GI, González-Aguilar GA, Benitez-Enriquez YE, Paredes-Alonso A, Jacobo-Cuellar JL, ... Parra-Quezada RA (2019). Yield, quality and phytochemicals of organic and conventional raspberry 
cultivated in Chihuahua. Notulae Botanicae Horti Agrobotanici Cluj-Napoca 47(2):522-530. https://doi.org/10.15835/nbha47211385

García-Ruiz MT, Mendoza-Castillo VM, Valadez-Moctezuma E, Muratalla-Lúa A (2013). Initial assessment of natural diversity in Mexican fig landraces. Genetics and Molecular Research 12(3):3931-3943. https://doi.org/10.4238/2013.September.23.12

Harzallah A, Mnari BA, Amri Z, Soltana H, Hammami M (2016). Phytochemical content and antioxidant activity of different fruit parts juices of three figs (Ficus carica L.) varieties grown in Tunisia. Industrial Crops and Products 83:255-267. https://doi.org/10.1016/j.indcrop.2015.12.043

Irfan PK, Vanjakshic V, Keshava-Prakasha MN, Ravie R, Kudachikar VB (2013). Calcium chloride extends the keeping quality of fig fruit (Ficus carica L.) during storage and shelf-life. Postharvest Biology and Technology 82:70-75. https://doi.org/10.1016/j.postharvbio.2013.02.008

Jagota S, Dani H (1982). A new colorimetric technique for the estimation of vitamin C using Folin phenol reagent. Analytical Biochemistry 127(1):178-182. https://doi.org/10.1016/0003-2697(82)90162-2

Kamiloglu S, Capanoglu E (2013). Investigating the in vitro bioaccessibility of polyphenols in fresh and sun-dried figs (Ficus carica L.). International Journal of Food Science and Technology 48(12):2621-2629. https://doi.org/10.1111/ijfs. 12258

Karabulut OA, Ilhan K, Arslan U, Vardar C (2009). Evaluation of the use of chlorine dioxide by fogging for decreasing postharvest decay of fig. Postharvest Biology and Technology 52(3):313-315. https://doi.org/10.1016/j.postharvbio.2009.01.006

King ES, Hopfer H, Haug MT, Orsi JD, Heymann H, Crisosto GM, Crisosto CH (2012). Describing the appearance and flavor profiles of fresh fig (Ficus carica L.) cultivars. Journal of Food Science 77(12):S419-S429. https://doi.org/10.1111/j.1750-3841.2012.02994.x

Mendoza-Castillo VM, Pineda-Pineda J, Vargas-Canales J, Hernández-Arguello E (2019). Nutrition of fig (Ficus carica L.) under hydroponics and greenhouse conditions. Journal of Plant Nutrition 42(11-12):1350-1365. https://doi.org/10.1080/01904167.2019.1609510

Mendoza-Castillo VM, Vargas-Canales JM, Calderón-Zavala G, Mendoza-Castillo MC, Santacruz-Varela A (2017). Intensive production systems of fig (Ficus carica L.) under greenhouse conditions. Experimental Agriculture 53(3): 339-350. https://doi.org/10.1017/S0014479716000405

Moreno-Pérez EC, Sánchez-del Castillo F, Gutiérrez-Tlaque J, González-Molina L, Pineda-Pineda J (2015). Greenhouse lettuce production with and without nutrient solution recycling. Revista Chapingo Serie Horticultura 21(1):4355. https://doi.org/10.5154/r.rchsh.2013.12.047

Neves LC, Rodrigues AC, Vieites RL (2002). Polietileno de baixa densidade (pebd) na conservação póscolheita de figos CV. "Roxo de Valinhos" [Low density polyetilene (ldpe), in the postharvest conservation of fig cv. "Roxo de Valinhos" stored under cold storage]. Revista Brasileira de Fruticultura 24(1):57-62. https://www.scielo.br/scielo.php?script=sci_issuetoc\&pid=0100-294520020001\&Ing=pt\&nrm=iso

Núñez-Castellano K, Castellano G, Ramírez-Méndez R, Sindoni M, Marin RC (2012). Efecto del cloruro de calcio y una cubierta plástica sobre la conservación de las propiedades organolépticas de la fresa (Fragaria $\times$ Ananassa Duch) [Effect of calcium chloride and a plastic cover on the conservation of properties organoleptic strawberry (Fragaria $\times$ ananassa Duch)]. Revista Iberoamericana de Tecnología Postcosecha 13(1):21-30.

Okatan K (2020). Antioxidant properties and phenolic profile of the most widely appreciated cultivated berry species: A comparative study. Folia Horticulturae 32(1):79-85. https://doi.org/10.2478/fhort-2020-0008

Quintero-Hilario CC, Esparza-Torres F, García-Mateos MR, Ybarra-Moncada MC, Hernández-Ramos L (2019). Effect of roasting on the nutritional value and antioxidant components of Maya nut (Brosimum alicastrum: Moraceae). Revista Chapingo Serie Horticultura 25(3):199-212. https://doi.org/10.5154/r.rchsh.2019.03.007

Salas-Salazar NA, Molina-Corral FJ, Dávila-Aviña JE, Parra-Quezada RA, Robles-Hernández L, Olivas-Orozco GI (2017). Influencia del almacenamiento en la síntesis de compuestos volátiles de manzana "Red Delicious" [Influence of storage on the synthesis of volatile apple compounds "Red Delicious"]. Revista Mexicana de Ciencias Agrícolas 8(1):223-231. https://doi.org/10.29312/remexca.v8i1.86

SIAP (2019). Agricultural and Livestock Information System [In Spanish]. Retrieved 2020 June 4 from https://nube.siap.gob.mx/cierreagricola/

Slatnar A, Klancar U, Stampar F, Veberic R (2011). Effect of drying of figs (Ficus carica L.) on the contents of sugar, organic acids, and phenolic compounds. Journal of Agricultural and Food Chemistry 59:11696-11702. https://doi.org/10.1021/jf202707y 
Sozzi GO, Abrajan-Villaseñor MA, Trinchero GD, Fraschina AA (2005). Postharvest response of 'Brown Turkey' figs (Ficus carica L.) to the inhibition of ethylene perception. Journal of the Science of Food and Agriculture 85(14):2503-2508. https://doi.org/10.1002/jsfa.2296

Steiner A (1984). The universal nutrient solution. ISOSC, Netherlands.

Valle-Guadarrama S, Alonso-Campos A, Alia-Tejacal I (2008). Atmósferas con bajo $\mathrm{O}_{2}$ y alto $\mathrm{CO}_{2}$ para la conservación de frutos de litchi [Low $\mathrm{O}_{2}$ and high $\mathrm{CO}_{2}$ atmospheres for preservation of litchi fruits]. Revista Fitotecnia Mexicana 31(2):157-164. https://www.revistafitotecniamexicana.org/31-2.html

Villalobos MC, Ansah F, Amodio ML, Serradillas MJ, Colelli G (2017). Application of modified atmosphere packaging with moisture absorber to extend the shelf life of 'Domenico Tauro' breba fruit. Acta Horticulturae 1173:365370. https://doi.org/10.17660/ActaHortic.2017.1173.63

Villalobos MC, Martin A, Ruiz-Moyano S, Martín E, Córdoba MG, Serradillas MJ (2015a). Effect of modified atmosphere packaging on the antioxidant activity and total phenolic content in 'Albacor' figs. Acta Horticulturae 1079:573-579. https://doi.org/10.17660/ActaHortic.2015.1079.77

Villalobos MC, Serradilla MJ, Martin A, Ruiz-Moyano S, Pereira C, Córdoba MG (2018a). Use of equilibrium modified atmosphere packaging for preservation of 'San Antonio' and 'Banane' breba crops (Ficus carica L.). Postharvest Biology and Technology 98:14-22. https://doi.org/10.1016/j.postharvbio.2014.07.001

Villalobos MC, Serradillas MJ, Martin A, Aranda E, López-Corrales E, Córdoba MG (2018b). Influence of modified atmosphere packaging (MAP) on aroma quality of figs (Ficus carica L.). Postharvest Biology and Technology 136:145-151. https://doi.org/10.1016/j.postharvbio.2017.11.001

Villalobos MC, Serradillas MJ, Martin A, Aranda E, López-Corrales E, Pereira C, Córdoba MG (2015b). Preservation of different fig cultivars (Ficus carica L.) under modified atmosphere packaging during cold storage. Journal of the Science of Food and Agriculture 96(6):2103-2115. https://doi.org/10.1002/jsfa.7326

Waterman PG, Mole S (1994). Methods in ecology. Analysis of phenolic plant metabolites. Blackwell Scientific Publications, Oxford.

Wojdyło A, Nowicka P, Carbonell-Barrachina AA, Hernández F (2016). Phenolic compounds, antioxidant and antidiabetic activity of different cultivars of Ficus carica L. fruits. Journal of Functional Foods 25:421-432. https://doi.org/10.1016/j.jff.2016.06.015

Zhang W, Li X, Zheng J, Wang G, Sun C, Ferguson I, Chen K (2008). Bioactive components and antioxidant capacity of Chinese bayberry (Myrica rubra Sieb. and Zucc.) fruit in relation to fruit maturity and postharvest storage. European Food Research and Technology 227:1091-1097. https://doi.org/10.1007/s00217-008-0824-Z

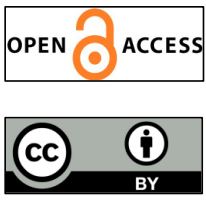

The journal offers free, immediate, and unrestricted access to peer-reviewed research and scholarly work. Users are allowed to read, download, copy, distribute, print, search, or link to the full texts of the articles, or use them for any other lawful purpose, without asking prior permission from the publisher or the author.

License - Articles published in Notulae Botanicae Horti Agrobotanici Cluj-Napoca are Open-Access, distributed under the terms and conditions of the Creative Commons Attribution (CC BY 4.0) License. (c) Articles by the authors; UASVM, Cluj-Napoca, Romania. The journal allows the author(s) to hold the copyright/to retain publishing rights without restriction. 